After the Massacre 


\section{ASIA: LOCAL STUDIES/GLOBAL THEMES}

Jeffrey N. Wasserstrom, Kären Wigen, and Hue-Tam Ho Tai, Editors

I. Bicycle Citizens: The Political World of the Japanese Housewife, by Robin M. LeBlanc

2. The Nanjing Massacre in History and Historiography, edited by Joshua A. Fogel

3. The Country of Memory: Remaking the Past in Late Socialist Vietnam, by Hue-Tam Ho Tai

4. Chinese Femininities/Chinese Masculinities: A Reader, edited by Susan Brownell and Jeffrey N. Wasserstrom

5. Chinese Visions of Family and State, I915-1953, by Susan L. Glosser

6. An Artistic Exile: A Life of Feng Zikai (1898-1975), by Geremie R. Barmé

7. Mapping Early Modern Japan: Space, Place, and Culture in the Tokugawa Period, I603-1868, by Marcia Yonemoto

8. Republican Beijing: The City and Its Histories, by Madeleine Yue Dong

9. Hygienic Modernity: Meanings of Health and Disease in Treaty-Port China, by Ruth Rogaski

Io. Marrow of the Nation: A History of Sport and Physical Culture in Republican China, by Andrew D. Morris

I I. Vicarious Language: Gender and Linguistic Modernity in Japan, by Miyako Inoue

I2. Japan in Print: Information and Nation in the Early Modern Period, by Mary Elizabeth Berry

I3. Millennial Monsters: Japanese Toys and the Global Imagination, by Anne Allison

I4. After the Massacre: Commemoration and Consolation in Ha My and My Lai, by Heonik Kwon 


\section{After the Massacre}

Commemoration and Consolation in Ha My and My Lai

\section{Heonik Kwon}

With a Foreword by Drew Faust

따

UNIVERSITY OF CALIFORNIA PRESS

Berkeley · Los Angeles · London 
University of California Press, one of the most distinguished university presses in the United States, enriches lives around the world by advancing scholarship in the humanities, social sciences, and natural sciences. Its activities are supported by the UC Press Foundation and by philanthropic contributions from individuals and institutions. For more information, visit www.ucpress.edu.

University of California Press

Berkeley and Los Angeles, California

University of California Press, Ltd.

London, England

(C) 2006 by The Regents of the University of California

Library of Congress Cataloging-in-Publication Data

Kwon, Heonik, I962-

After the massacre : commemoration and consolation in Ha My and My Lai / Heonik Kwon ; with a foreword by Drew Faust.

p. cm. - (Asia-local studies/global themes ; I4) Includes bibliographical references and index. ISBN-I 3: 978-0-520-24796-3 (cloth : alk. paper) ISBN-IO: 0-520-24796-5 (cloth : alk. paper) ISBN-I 3: 978-0-520-24797-O (pbk. : alk. paper) ISBN-IO: 0-520-24797-3 (pbk. : alk. paper)

I. My Lai Massacre, Vietnam, I968. 2. My Lai 4 (Vietnam)-Historiography. 3. Vietnamese Conflict, I96I-I975-Atrocities. I. Title. II. Series.

DS557.8.M9K96 2006

$959.704^{\prime} 342-\mathrm{dc} 22$

2005037445

Manufactured in the United States of America

$\begin{array}{llllllllll}\text { I } 5 & \text { I } 4 & \text { I3 } & \text { I2 } & \text { II } & \text { IO } & 09 & 08 & 07 & 06\end{array}$

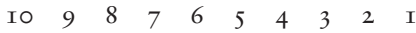

This book is printed on New Leaf EcoBook 50, a I00\% recycled fiber of which $50 \%$ is de-inked post-consumer waste, processed chlorine-free. EcoBook 50 is acid-free and meets the minimum requirements of ANSI/ASTM D5634-OI (Permanence of Paper). 